\title{
The Research Review of Accounting Firm Transformation*
}

\author{
Zhaoyang Wang ${ }^{1,2}$ \\ ${ }^{1}$ Economy\& management school of Wuhan university, ${ }^{2}$ Hunan university of finance and economy, Wuhan/ Changsha China. \\ Email: zhaoyangwang@126.com
}

Received July, 2013

\begin{abstract}
While China's accounting firms are focusing on purely for the limited liability partnership, the study on the form of accounting firm organization becomes more and more warmly. We specifically analyzed the research achievement of accounting firm organization form in Britain and China, and put forward of the prospect and direction for the study on accountant firm transformation theory in our country
\end{abstract}

Keywords: Limited Liability Partnership; Accounting Firm; Research Review

\section{Introduction}

On July 21, 2010, the ministry of finance and the state administration of industry and commerce administration jointly issued "the provisional regulation of promoting the large and medium-sized accounting firms to adopt limited liability partnership organization form"(accounting [2010] 12), accountant firms in our country started the tidal wave for the limited liability partnership transformation. So far, there are 33 transferred accountant firms in China excluding branch offices, 111 ones including branch offices; these are important measures for public accounting firms in our country to better themselves and to meet the internationality.

Since the limited liability partnership implemented, there are more and more researches on it, through the overall analysis on research achievements of accounting firm organization especially limited liability partnership organization in the last few years, we aim to provide theoretical guidance for the transformation of public accounting firms in our country, and to promote the innovation of the auditing theory research with the core of limited liability partnership organization.

\section{Britain and America Research Status}

British as the birthplace of certified public accountants always has a melody of partnership for its organization form, same with Britain, in the early days of the United States, the main organization form of accounting firms is also ordinary partnership, limited liability partnership organization is widely used in large-scale public ac-

\footnotetext{
*Humanities and social sciences youth project of the education ministry (12 YJC790247), Hunan soft science project (2011ZK3025), and Hunan social science fund project (08 YBA151)
}

counting firm, law firms and other professional partnership enterprises in the United States since 1996, the four biggest accounting firms are already using the organization form. There is only a few foreign researches on accounting firm transformation, and foreign scholars did not take special research on accounting firm organization, the research of its organization form is mainly from the legal perspective, it's mainly including distinction between the legal responsibility system of faults and negligence registered accountant, the impaction on supply and demand in audit market, investor's wealth, auditor's effort degree and social wealth effect that caused by the difference of investor's damage distribution system and the difference of legal responsibility level of the registered accountant.

\subsection{Researches on Organization form of Accounting Firm Partnership}

The organization form of accounting firm will have an huge impact on accounting firms and even the whole audit market. There are some kinds of foreign accounting firm organization forms as common partnership, Limited Liability Company, limited liability partnership. Different organization form will have different aggregate effect to audit market. For instance, Alchian and Demsetz (1972) thought that is more likely for professional knowledge skilled team to adopt partnership organizational form, through the analysis on knowledge structure and psychology factors. Accounting firm itself is with senior professional and technical staff, and is different from general enterprise in the human resources, so it is more suitable for accounting firm to adopt partnership organization form. Balachandran and Laurence (1999) use agency theory to make further analysis on the nature 
of the partnership organization form in accounting firm and its effect on accounting firm.

\subsection{Researches on Limited Liability Partnership}

The main organization form of accounting firm is limited liability partnership in Britain and America, so the research on accounting firm transferring to limited liability partnership is not seen much in recent 10 years, and the study is mainly focused on only the limited liability partnership. Such as Hamilton, Robert w. (1994) analyzed the origin of the limited liability partnership, and further analyzed the organization form of 6 international accounting firms. Prem Sikka (2008) analyzed the pros and cons of capital internationalization from the point of limited liability partnership. Carter g. Bishop made a comparative analysis for ordinary partnership, limited liability partnership, company organization form, and put forward improvement Suggestions for limited liability partnership.

\subsection{Researches on the Influence on Auditor'S Legal Responsibility by Accounting Firm Organization Form}

Dopuch and King (1992) used experimental economics research methods to assess effects on the supply and demand of audit service by three different auditor legal responsibility systems, including fault legal responsibility system, strict proof-no-need common fault or deliberate fault legal responsibility system and no legal liability system. Narayanan (1994) established the audit quality and auditors legal responsibility model; through the model analysis, he concluded that because of the proportion legal responsibility system, compared to the joint and individual legal responsibility, the auditor litigation costs is more sensitive to the degree of efforts, when the legal responsibility distribution rules between auditors and company transferred from proportion legal responsibility to auditors' joint legal responsibility or auditors' sole legal responsibility, audit quality will improve. Schwartz (1998) established a mathematics model of auditor legal responsibility system, fuzzy necessary attention and auditing standards, through the model analysis, the author reached a conclusion, the auditor effort degree caused by the fuzzy fault legal responsibility system, was significantly lower than the highest degree of auditor's efforts in clear legal responsibility system. Through the method of constructing model, Radhakrishnan (1999) test the difference of investor wealth and auditors effort degree under two different legal liability system: attention necessary legal responsibility system and strict attention legal responsibility system. With the mathematical model, Ewet, Feess and Nell (2000) tested auditor's legal liability system in the environment of im- perfect information, litigation costs and is risk-aversion auditor. The results of the study showed that in the environment of imperfect information, litigation costs and are risk-aversion auditor, auditor negligence legal system failed; auditor would positively deviate from any given kind of criteria. Liu and Wang (2006) established the mathematics model of company investment decision, auditor effort degree, audit costs and company pricing, in two auditor legal liability systems: negligence legal responsibility system and strict legal responsibility system. Through the analysis, the authors draw the following conclusion: auditor efforts level in strict legal responsibility system is the optimal level, but in fault legal responsibility system is not.

\section{Chinese Accounting Firm Organization Research Status}

It can be seen from the organization form of accounting firm in Britain and America that accounting firm organization form of foreign mainstream countries transferred mainly from ordinary partnership to the limited liability partnership, and the organization form of accounting firm in our country is mainly limited liability partnership. Since 2010, the government stressfully promoted accounting firms to the limited liability partnership, and domestic research about the organization form of accounting firm, mainly concentrated in that how accounting firms in our country to select the adaptable organization form.

\subsection{Researches on the Choice of Accounting Firm Organization Form}

Most scholars believed that the organization form of our accounting firm should have international convergence, and pick the choice of limited liability partnership as in Britain and America. Huang Jieli (2010) thought that our limited liability partnership is a new accounting firm organization form with Chinese characteristics and is suitable for China's national conditions; Meng Xiaojun, Yan Hui (2010)) thought that it should be a development direction for our accounting firms turning to limited liability partnership. And part of the scholars put forward their own thinking on the promotion of limited liability partnership in China. Qin Rongsheng (2010) thought that we should not take "one size fits all" approach to the transformation of accounting firm, and we should seek a balance among the benefit protection of partner, creditors, and the public. Yu Yumiao(2002) thought that China cannot veto the rights for accounting firms to choose their organization form independently, while actively promoting the partnership restructure of accounting firms. 


\subsection{Researches on the Relationship between Accounting Firm Organization Form and Audit quality}

An Guangshi, Yang Shanying (2011) thought that limited liability accounting firm in majority lead ultra commercial behavior produced by some accounting firms, and infect audit quality; through the empirical test, Yuan Hongqi (2003) thought that the organization form and scale of accounting firm have no obvious influence on audit opinion. Lei Guangyong, Cao Jian (2008) analyzed and demonstrated the audit legal system mainly from the point of the social cost, the model derivation results showed that different legal punishment ways and loss measuring models will produce a significantly different influence to incent auditors, and impact audit quality for further. By establishing a audit quality quadratic function model, Liu Bin, Wang Xingfen, Li Jiaming (2008) analyzed the influence the externality of audited financial report bought to audit failure while accounting firms with different organization form is auditing multiple clients.

\subsection{Researches on Limited Liability Partnership Organization Form}

On the basis of the practice of limited liability partnership in Zhong-Yue-Rui-Hua accounting firm, Zhang Lianqi (2011) deeply analyzed the necessity, basic characteristics, and responsibility configuration of limited liability partnership and specific procedure of the transferring. Started from limited liability partnership in countries as Britain and the USA, Chen Zhisheng (2011) put forward the suggestion that our limited liability partnership should be perfected from division of common responsibility and proof responsibility scope among Limited liability partners, risk fund and professional insurance system, supervision of limited liability partnership and so on. He Xinrong (2010) thought that limited liability partnership aim at providing limited liability protection to some partners, but not providing effective protection measures to creditors at the same time, this would definitely bring theoretical and practical problem to the development of limited liability partnership which was increasingly prospering. On this consideration, we need to adopt related provisions of American legislation, and give protection to creditors with the principle of fair and efficiency.

\section{Research Prospect of Chinese Accountant Firm Transformation}

Relevant research results above at home and abroad, provides us with enlightenment of good theoretical basis and beneficial research methods, and some limitations in general. The research results abroad mainly started from the legal responsibility, without special research on the effects of the audit market caused by the change of organizational form, and there is no accounting firm of limited liability company abroad, therefore we cannot learn from foreign research achievements about accounting firm of limited liability company changing to limited liability partnership. And the domestic research mainly focus on how should our country to choose a CPA firm's organization form, research on the influence mechanism limited of limited liability partnership to audit market is almost not involved. At the same time, because China's accounting firm is large-scale transferring to the limited liability partnership, there is no specific research on overall effect of limited liability partnership in our audit market so far.

\subsection{The Influences of Accounting Firm in Our Country Turning to Limited Liability Partnership}

Our accounting firms running into the transformation of limited liability partnership as a trend will definitely rise far-reaching effect on accounting firm themselves and China's audit market. The transformation of accounting firm will provide background support for theory study from following aspects.

1) The organization form of accounting firm will impact audit market, so does audit opinion even audit quality. Accounting firm organization form mainly contains three kind, common partnership, limited liability partnership, and limited liability company. the choice of organization form will affect the legal responsibility of auditor, and then to the audit opinion even audit quality.

2) Accounting firm transferring to limited liability partnership will affect its audit behavior and audit performance, and because of the mass concentration of transferring behavior, it will impact audit performance of whole Chinese market. Most of our accounting firms are limited liability company, followed by ordinary partnership, the concentrative transformation since 2010 will have greater effect on performance of audit market overall.

3) With the transferring to limited liability partnership, independence of the certified public accountants, the development of accounting firms, and the development of Chinese audit market will gradually match British and American. China's limited liability partnership is in fact the same as in Britain and America. Our concentrative transferring to limited liability partnership is showing that the organization form of China's accounting firm is drawing close to that of Britain and America, then lay the foundation for the internationalization of our accounting firms.

\subsection{The Few Empirical Study of Accounting Firm Transformation}

The study of the theory about accounting firm transfor- 
mation is not scarce, but there is no empirical research on how to measure the influence that transferring put on accounting firm itself and the entire audit market at present. We can carry on empirical research from the following aspects.

1) The special opportunity that our accounting firm transfer to limited liability partnership at present stage provide us natural testing area to study the impact on audit market caused by the transformation. Therefore, it is innovative for us to research the effect in audit opinion, audit quality, audit performance before and after the transformation in an accounting firm.

2) Meanwhile just because our transformation to limited liability partnership is underway, we can dynamically track different behavior of limited liability partnership accounting firm transferred from different organization form. So the researchers can have an innovation in research data.

3) At present, the domestic empirical research on the overall effect of transformation cause to audit market has not been started. we can build econometrics model for investigation on the transferring effect of accounting firm in audit market, through empirical demonstration, we aim to find out the difference of audit quality and audit market performance, before and after the transformation. Then we can provide theoretical and empirical basis for after- transformation accounting firms and accountants to behave.

\subsection{Theoretic Framework of Limited Liability Partnership Has Not Been Established}

The theory research and specific operation program about limited liability partnership is heated at present. With the gradual completing of accounting firm transformation, there will be more and more researches about effect caused by limited liability partnership on internal management of accounting firm, auditor, and the entire accounting firm. Through the further research on limited liability partnership organization form, we can provide new ideas and research direction for the interior management our accounting firm.

\section{REFERENCES}

[1] S. M. Chen, S. Y. J. Sun and D. H. Wu, "Client Importance, Institutional Improvements, and Audit Quality in China: An Office and Individual Auditor Level Analysis," The Accounting Review, Vol. 85, No. 1 2010, pp. 127-158. doi:10.2308/accr.2010.85.1.127

[2] C. W. Liu and T. C. Wang, "Auditor Liability and Business Investment," Contemporary Accounting Research, Vol. 4, 2006, pp. 1051-1071. doi:10.1506/E023-337T-180P-18U4

[3] A. Ferguson and D. Stokes, "Brand Name Audit Pricing, Industry Specialization, and Leadership Premiums Post-Big 8 and Big 6 Mergers,” Contemporary Accounting Research, Vol. 19, No. 1, 2002, pp. 77-110.

[4] R. Ewert, E. Feess and M. Nell, “Auditor Liability Rules under Imperfect Information, and Costly Litigation: The Welfare-increasing Effect of Liability Insurance," The European Accounting Review, 2000, Vol. 9, No. 3, pp. 371-385. doi:10.1080/09638180020017122

[5] Schwartz. Auditors' Liability, "Vague Due Care, and Auditing Standards," Review of Quantitative, Finance and Accounting, 1998(11), pp. 183-207.

[6] V. G. Narayanan, "An Analysis of Auditor Liability Rules,” Journal of Accounting Research, 1994, pp. 39-59. doi:10.2307/2491438

[7] N. Dopuch and R. King, "Negligence Versus Strict Liability Regimes in Auditing: An Experimental Investigation, The Accounting Review,1992, Vol. 1, pp. 97-120. 